\title{
The 47th Annual Meeting of the European Society for Blood and Marrow Transplantation: Welcome Address
}

Published online: 24 June 2021

(c) Springer Nature Limited 2021

14-17 March, $2021 \bullet$ Virtual Meeting

Copyright: Modified and published with permission from https://www.ebmt.org/annual-meeting

Sponsorship Statement: Publication of this supplement is sponsored by the European Society for Blood and Marrow Transplantation.

The EBMT is honoured to invite you to the 47th EBMT Annual Meeting, which will take place virtually, 14th-17th March, 2021.

More than 6700 delegates attend the EBMT Annual Meeting. Our top-notch scientific programme for physicians, nurses, data and quality managers, pharmacists, psychologists, transplant coordinators, and other medical professionals continues to evolve and develop, with additional new topics added every year.

The EBMT 2021 Scientific Programme will offer a great selection of symposia and educational sessions related to the current challenges of haematopoietic stem cell transplantation (HSCT) and cell therapy.
We look forward to welcoming you to the 47th Annual Meeting of the EBMT, and the second fully virtual edition at EBMT 2021!

Rafael F. Duarte - Congress President

Anna Sureda - Scientific Chair

Julia Ruiz-Pato and Isabel Salcedo - Local Nurses Chair Michelle Kenyon - President Elect of the Nurses Group John Murray - President of the Nurses Group Nicolaus Kröger - EBMT President 